\title{
Photovoltaic Modules Selection from Shading Effects on Different Materials
}

\author{
Guoqian Lin ${ }^{1,2}$, Samuel Bimenyimana ${ }^{1,3}$, Ming-Lang Tseng $4,5,6, * \mathbb{D}$, Ching-Hsin Wang ${ }^{7}$, \\ Yuwei Liu ${ }^{1,2}$ and Lingling $\mathrm{Li}^{1,2}$ \\ 1 State Key Laboratory of Reliability and Intelligence of Electrical Equipment, Hebei University of Technology, \\ Tianjin 300130, China; 201611401005@stu.hebut.edu.cn or lingchant@gmail.com (G.L.); \\ s0785213122@gmail.com or sam@hqu.edu.cn (S.B.); 201811401014@stu.hebut.edu.cn or \\ yuweiresearch@gmail.com (Y.L.); lilinglinglaoshi@126.com or lilingling@hebut.edu.cn (L.L.) \\ 2 Key Laboratory of Electromagnetic Field and Electrical Apparatus Reliability of Hebei Province, \\ Hebei University of Technology, Tianjin 300130, China \\ 3 Intelligence and Automation in Construction Fujian Province, Higher-Educational Engineering Research \\ Centre, Huaqiao University, Xiamen 361021, China \\ 4 Institute of Innovation and Circular Economy, Asia University, Taichung 41354, Taiwan \\ 5 Department of Medical Research, China Medical University Hospital, China Medical University, \\ Taichung 40402, Taiwan \\ 6 Faculty of Economics and Management, Universiti Kebangsaan Malaysia, Bangi 43600, Selangor, Malaysia \\ 7 Institute of Project Management, Department of Leisure Industry Management, National Chin-Yi University \\ of Technology, Taichung 41170, Taiwan; chwang@ncut.edu.tw \\ * Correspondence: tsengminglang@gmail.com or tsengminglang@asia.edu.tw
}

Received: 5 November 2020; Accepted: 10 December 2020; Published: 15 December 2020

\begin{abstract}
This study aims to provide photovoltaic module selection with better performance in the shading condition for improving production efficiency and reducing photovoltaic system investment cost through the symmetry concept, combining both solar energy mathematical and engineering principles. The study builds a symmetrical photovoltaic model and uses the series-parallel circuit theory, piecewise function and Matlab simulation. The voltage and current output characteristics of commercial photovoltaic modules made of different materials and structures are analyzed and their shading effects are evaluated. The results show that for each photovoltaic module, the output power is directly proportional to the irradiance. The output voltage of the photovoltaic module slightly increases and the output current greatly decreases from no shading to shading. The rate of output power reduction varies for each photovoltaic module type when the irradiance changes. The thin film modules show a lower output power reduction rate than crystalline photovoltaic modules from no shading to shading and they have good adaptability to shading. The use of thin film photovoltaic modules is recommended when the shading condition cannot be avoided.
\end{abstract}

Keywords: solar energy; photovoltaic materials; irradiance; power reduction; shading effect

\section{Introduction}

The energy crisis and environmental pollution have become a problem that cannot be ignored due to the continuous consumption of fossil fuels [1-3]. The development and utilization of solar energy and wind energy as renewable technologies are effective means to solve these problems with the help of science and technology progress [4,5]. Solar energy has large resource reserves and pollution-free and low-cost characteristics compared with fossil fuels [6,7]. Solar energy development and utilization have the potential to reduce fuel consumption and protect the environment [8-11]. The photovoltaic industry is an indispensable part of the power system; however, Pannebakker et al. [12] argued that 
the solar cells' working efficiency would be reduced during shading. Once shaded, the photovoltaic system's installation capacity must be increased to meet the user's power demand because solar photovoltaic panels generate electricity by a photovoltaic effect after receiving sunlight [13-15].

The literature shows that sunlight illumination is important for the photovoltaic power generation industry [16-18]. For instance, Saini et al. [19] argued that stable sunlight exposure is among the basic facts to maintain an isolated photovoltaic micro-grid to meet the load demand. However, during photovoltaic power generation, trees, fallen leaves, houses and clouds may block and shade the sunlight that is to shine on the photovoltaic panel, resulting in a voltage and current mismatch of photovoltaic modules and affecting the output power [20,21]. The voltage, current mismatch and power reduction level depend on different factors, for example, the photovoltaic cell material (structure and its inner material properties), climatic weather conditions and installation site location [22].

The structure of photovoltaic modules, the degree of light shielding and the total sunshine amount are important to photovoltaic modules [23]. The current, voltage and power of photovoltaic cells change when the sunlight is blocked/shaded. Solar cells are usually connected in series for the purpose of increasing the voltage and power to a level higher than that of one single cell, and a parallel bypass diode is generally used to protect solar cells in order to avoid damage to photovoltaic modules caused by shading $[24,25]$. The total amount of sunlight reaching the photovoltaic panel is reduced when the light is blocked, resulting in a power reduction in the photovoltaic system [26,27]. However, each solar cell in the string has its rated power. The load demand is met by increasing the installed capacity of the photovoltaic system when the output power of the off-grid photovoltaic system decreases, which increases the investment cost. Hence, it is significant to select photovoltaic modules with a low output power reduction rate under shading.

This study systematically investigates and chooses photovoltaic modules with a smaller power drop to reduce the investment cost of the system when shading cannot be avoided because it is practical and realistic that, in many cases, the photovoltaic output might be symmetric while providing an energy and electricity service to a load demand with an asymmetric behavior, all depending on the climatic weather conditions. Additionally, it presents the theoretical basis for off-grid photovoltaic users to select stable and reliable photovoltaic panels for the development of renewable energy, environmental protection and sustainable development. This is achieved through theoretical analysis and Matlab modeling, as well as the research on the variation in the voltage, current and output power of commercial photovoltaic modules under shading.

The contributions of this study are as follows: (1) building a photovoltaic module's mathematical model; (2) analyzing the voltage and current characteristics of photovoltaic modules; (3) studying the voltage change rule and photovoltaic modules with the degree of shading; (4) analyzing the change of output power of different photovoltaic modules under shading; and (5) finding out the photovoltaic modules with a lower output power reduction rate in the case of shading and providing a theoretical basis for photovoltaic users to select the appropriate modules.

The rest of this study is organized as follows. The second part introduces the commonly used photovoltaic materials and related literature in the photovoltaic field. The third part analyzes the variation in the voltage, current and power of photovoltaic modules under shading. The fourth part studies the performance parameters of the eight selected photovoltaic modules made of different materials under different shading levels. The fifth part discusses the significance of this study. Finally, the concluding remarks, shortcomings and future directions are presented.

\section{Literature Review}

The structural, chemical, metallurgical and physical properties of different materials strongly depend on deposition parameters such as intrinsic carrier concentration, bandgap level, absorption capacity, recombination, electron affinity and resistivity. Prior studies on photovoltaic materials show that there are plenty of photovoltaic materials, and each material type is suitable for its own specific application. The commonly used materials for preparing solar cells include silicon, copper indium 
selenium, cadmium telluride, gallium arsenide and copper indium selenide $[28,29]$. Solar cells made of these materials are divided into two categories: thin film solar cells and crystalline solar cells [30]. Thin film solar cells are made by depositing one or several layers of photovoltaic materials on a substrate to obtain wide absorption spectrum characteristics and better diffuse radiation performance.

The performance variation is due to the range of wavelengths absorbed by the different glazing types. Crystal solar cells absorb long-wave radiation; thin film solar cells absorb a wide spectrum range and absorb short-wave blue light on the days with large clouds or low solar radiation. Thin film solar cells are designed and connected in parallel rather than in long series. For instance, Hegedus [31] argued that the key difference between crystalline module technology and thin film module technology is their shade resistance due to the string length. The property of better low-light level performance of thin film photovoltaic modules allows them to perform better at lower light intensity such as shade, cloudy or dull weather climates [32]. Zhou et al. [33] argued that thin film solar cells have better performance at low light intensity by adjusting the absorption spectrum to respond to the wide frequency range of sunlight. Thin film modules are tuned to absorb a wider infrared range than the crystal modules, thus providing a larger output at low light intensity. Crystal solar cells include single crystal solar cells, polycrystalline solar cells and ribbon solar cells. Thin film solar cells include amorphous silicon solar cells, cadmium telluride solar cells, copper indium selenium solar cells and organic solar cells.

Silicon is a common material for preparing monocrystalline silicon solar cells and polycrystalline silicon solar cells and has been introduced into the photovoltaic market for a long time [34]. Silicon (atomic number 14) is one of the chemical elements having electropositive and metalloid properties in the periodic table of chemical substances [35]. The conductivity of silicon increases with the increase in temperature and becomes an important semiconductor material in photovoltaic cell manufacturing. Silicon is an important reductant and alloy element in metallurgy in addition to being used as a semiconductor in photovoltaic cells [36]. Amorphous photovoltaic cells are made of direct band gap materials and belong to thin film photovoltaic cells.

In addition, amorphous silicon is deposited on the substrate at a temperature lower than $30{ }^{\circ} \mathrm{C}$ which is a better choice for flexible substrate and roll-to-roll manufacturing technology [37]. For instance, Choi et al. [38] presented that amorphous silicon photovoltaic cells have the advantages of low manufacturing cost, strong market competitiveness, uniform structure and their overall characteristics not being easily affected by the outside environment conditions. Cadmium and tellurium are byproducts of zinc, copper and gold mining. Cadmium and tellurium are combined to form a material called cadmium telluride, an important material for thin film solar cells. Cadmium telluride has more advantages in the photovoltaic power generation industry due to its higher efficiency than silicon at high temperature and low illumination.

These studies examined photovoltaic modules' shading effect. Patel et al. [39] explored the factors affecting module performance under shading. Liu et al. [40] studied the relationship between the output of a photovoltaic array and temperatures and shading number. Zhao et al. [41] studied the relationship between the output of a photovoltaic module and shading area and transmittance factor. Prior studies on the shading effect were based on photovoltaic modules theoretical analysis with a certain photovoltaic material, while the influence of shading on photovoltaic modules with different materials and different structures has been left behind and ignored. This study analyzes the different photovoltaic modules' shading effect to find the appropriate photovoltaic modules for reducing the photovoltaic power generation system investment cost in a specific environment. The influence of shading on the voltage, current and output power of photovoltaic modules made of different materials is studied, and two different photovoltaic modules are selected for each photovoltaic material type in order to make the results more universal.

This study proposes that appropriate photovoltaic modules are recommended for users when shading cannot be avoided, according to the output power reduction rate of different photovoltaic modules in the shading situation. Hence, thin film photovoltaic modules have better sunshade 
adaptability than crystal photovoltaic modules and the output power reduction rate of thin film photovoltaic modules is lower in the case of sunshade. Thin film photovoltaic modules are recommendable for installation sites with persistent shade.

\section{Mathematical Modeling}

The photovoltaic power generation symmetric model was built in the Matlab/Simulink environment, as shown in Figure 1. The simulation model is composed of three solar cell strings $(g=3)$, and each string is composed of 20 solar cells in series $(h=20)$, as shown in Figure 1a. In order to protect the circuit, each cell string has a bypass diode in parallel, overall forming a symmetrical model structure, as shown in Figure 1b.

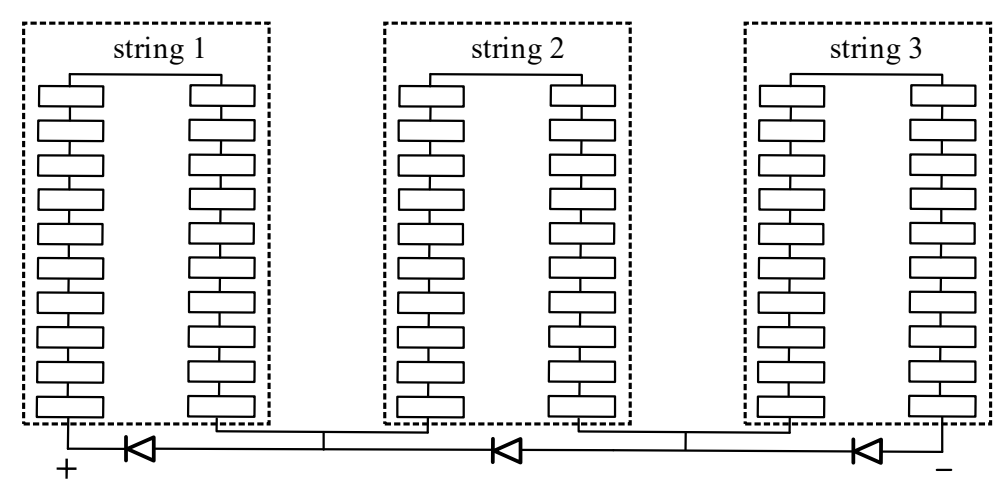

(a) Structure diagram of solar cell string

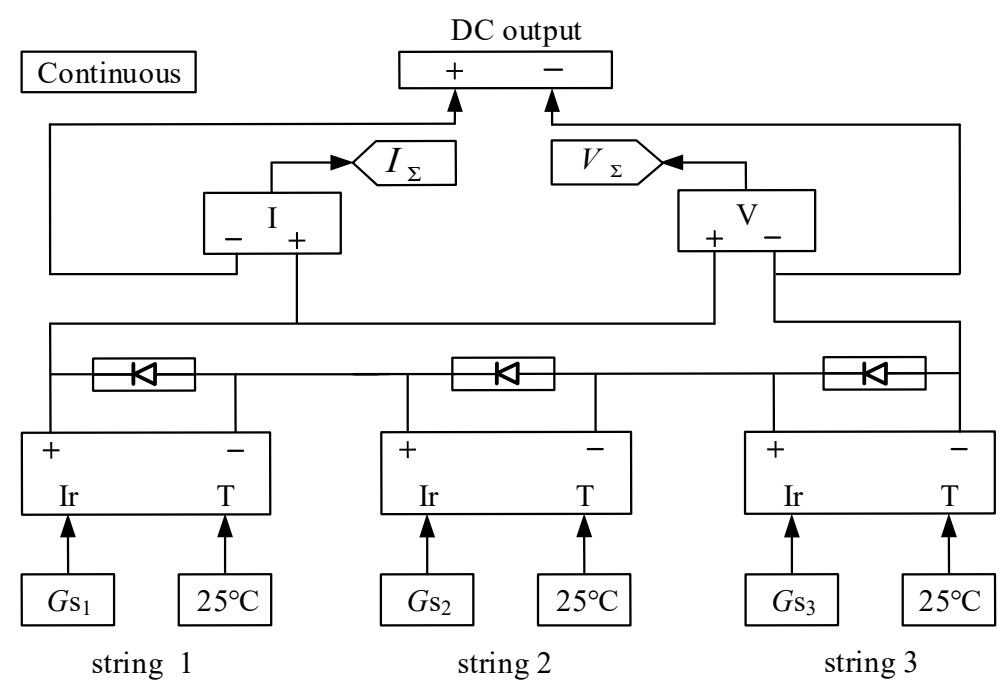

(b) General drawing of model

Figure 1. Simulation model of a photovoltaic module.

The current-voltage output characteristics of the model in Figure 1 are mathematically represented through Equation (1).

$$
\left\{\begin{array}{c}
I_{i j}=f\left(V_{i j}\right) \\
V_{j \Sigma}=\sum_{i=1}^{h} V_{i j} \\
I_{j \Sigma}=I_{i j}
\end{array}\left(\begin{array}{c}
i=1,2,3, \ldots 20 \\
j=1,2,3
\end{array}\right)\right.
$$

where $V_{j \Sigma}$ and $I_{j \Sigma}$ are the voltage and current outputs of the $j^{\text {th }}$ solar cell string; $I_{i j}=f\left(V_{i j}\right)$ represents the current-voltage (I-V) output characteristics of the $i^{\text {th }}$ solar cell in the $j^{t h}$ solar cell string; and $V_{i j}$ and $I_{i j}$ are the voltage and current at the maximum power point of the $i^{\text {th }}$ solar cell in the $j^{\text {th }}$ solar cell string under practical conditions. 
Furthermore, the current-voltage output characteristics, as expressed in Equation (1), are refined and expressed through a piecewise function as shown in Equation (2).

$$
\left(\begin{array}{cc}
I_{i j}=I_{\mathrm{SC} i j}\left[1-C_{1 i j}\left(\mathrm{e}^{\left.\left.V_{i j} / C_{2 i j} V_{\mathrm{OC} i j}-1\right)\right]}\right.\right. & I_{i j}, V_{i j}>0 \\
V_{i j}=0 & I_{i j} \geq I_{\mathrm{SC} i j} \\
I_{i j}=0 & V_{i j} \geq V_{\mathrm{OC} i j}
\end{array}\right.
$$

where $V_{\mathrm{OC} i j}$ and $I_{\mathrm{SC} i j}$ are the open-circuit voltage and short-circuit current of the $i^{\text {th }}$ solar cell in the $j^{\text {th }}$ solar cell string under practical conditions; and $C_{1 i j}$ and $C_{2 i j}$ both represent the inherent engineering coefficients of the solar cell.

In particular, the expressions of $C_{1 i j}$ and $C_{2 i j}$ are shown as follows.

$$
\begin{gathered}
C_{1 i j}=\left(1-I_{\mathrm{m} i j} / I_{\mathrm{scij}}\right) \mathrm{e}^{-V_{\mathrm{m} i j} / C_{2 i j} V_{\mathrm{OC} i j}} \\
C_{2 i j}=\left(V_{\mathrm{m} i j} / V_{\mathrm{OC} i j}-1\right)\left[\ln \left(1-I_{\mathrm{m} i j} / I_{\mathrm{SC} i j}\right)\right]^{-1}
\end{gathered}
$$

where $V_{\mathrm{m} i j}$ and $I_{\mathrm{m} i j}$ are the voltage and current at the maximum power point of the $i^{\text {th }}$ solar cell in the $j^{\text {th }}$ solar cell string under standard test conditions (STC).

According to Equations (1) and (2), the mathematical model is rewritten as follows.

$$
\left\{\begin{array}{c}
I_{j \Sigma}=f\left(V_{j \Sigma}\right) \\
I_{\Sigma}=\sum_{j=1}^{g} I_{j \Sigma} \quad(j=1,2,3 \ldots g) \\
V_{\Sigma}=V_{j \Sigma}
\end{array}\right.
$$

where $V_{\Sigma}$ and $I_{\Sigma}$ represent the output voltage and output current of the photovoltaic module.

The maximum output power of the photovoltaic module without shading is as follows.

$$
P_{\max }=\sum_{i=1}^{h} \sum_{j=1}^{g} P_{\max , i j}
$$

where $P_{\max , i j}$ is the maximum output power of the $i^{\text {th }}$ solar cell in the $j^{\text {th }}$ solar cell string of shaded photovoltaic cells.

With consideration of the normal irradiance intensity under standard test conditions as a reference $\left(G_{\text {ref }}: 1000 \mathrm{~W} / \mathrm{m}^{2}\right)$ and $G_{\mathrm{s}}$ as the irradiance intensity reaching the shaded photovoltaic cell string, the transfer factor $r$ of the photovoltaic module is expressed as follows.

$$
r=\frac{G_{\mathrm{s}}}{G_{\text {ref }}}
$$

In practice, the maximum output power of photovoltaic modules is expressed as follows.

$$
P_{\max , \text { all }}=P \times \sum_{j=1}^{g} r
$$

where $\sum_{j=1}^{g} r$ is the sum of power transfer factors; and $P$ stands for the nominal output power of the photovoltaic module $(\mathrm{g} \times \mathrm{h})$ when all the cell strings are receiving normal irradiance. 
From no shading to shading, the percentages of power change, current change and voltage change of photovoltaic modules are as follows.

$$
\begin{gathered}
\eta_{P}=\left(\frac{G M P-P_{\text {max all }}}{P_{\text {max all }}}\right) \times 100 \% \\
\eta_{I}=\left(\frac{I_{\text {shade }}-I_{\mathrm{mp}}}{I_{\mathrm{mp}}}\right) \times 100 \% \\
\eta_{V}=\left(\frac{V_{\text {shade }}-V_{\mathrm{mp}}}{V_{\mathrm{mp}}}\right) \times 100 \%
\end{gathered}
$$

where GMP is the global maximum power; $I_{\mathrm{mp}}$ and $V_{\mathrm{mp}}$ are the output current and output voltage of the photovoltaic module when there is no shading; and $I_{\text {shade }}$ and $V_{\text {shade }}$ are the output current and output voltage of the photovoltaic module when there is shading.

\section{Results}

The study object is the photovoltaic modules which are composed of monocrystalline, polycrystalline, amorphous, cadmium telluride, copper indium selenium, copper indium gallium selenium, hybrid amorphous monocrystalline and hybrid amorphous microcrystalline materials. In order to make the results more universal, two photovoltaic modules of different models are selected for each material. Table 1 shows the inherent electrical characteristics of various types of

\begin{tabular}{|c|c|c|c|c|c|}
\hline \multirow{2}{*}{ Types } & \multirow{2}{*}{ Materials } & \multicolumn{4}{|c|}{ Characteristic Parameters } \\
\hline & & $P_{\max }(\mathrm{W})$ & $V_{\mathrm{mp}}(\mathrm{V})$ & $I_{\mathrm{SC}}(\mathrm{A})$ & $I_{\mathrm{mp}}(\mathrm{A})$ \\
\hline GSM-240 & monocrystalline & 239.12 & 30.50 & 8.44 & 7.84 \\
\hline ASEC-245G6S69 & monocrystalline & 245.04 & 27.44 & 9.28 & 8.93 \\
\hline TSM-240PA05.18 & polycrystalline & 239.86 & 30.40 & 8.37 & 7.89 \\
\hline JKM240P-60B & polycrystalline & 240.09 & 30.20 & 8.54 & 7.95 \\
\hline TWSF-W-aSi-85W-1 & amorphous & 85.26 & 98.00 & 1.12 & 0.87 \\
\hline QS85EGF & amorphous & 85.75 & 87.50 & 1.19 & 0.98 \\
\hline FS-280 & cadmium telluride & 79.74 & 71.20 & 1.22 & 1.12 \\
\hline FS-395 & cadmium telluride & 95.00 & 47.50 & 2.17 & 2.00 \\
\hline SF80-US-P & copper indium selenium & 79.95 & 41.00 & 2.26 & 1.95 \\
\hline SF90-US-B & copper indium selenium & 90.00 & 45.00 & 2.30 & 2.00 \\
\hline STX-130 & copper indium gallium selenium & 130.00 & 56.80 & 2.60 & 2.29 \\
\hline TS-150C1 & copper indium gallium selenium & 150.07 & 48.10 & 3.45 & 3.12 \\
\hline SNPM-GX-220 & hybrid amorphous monocrystalline & 219.64 & 32.30 & 7.40 & 6.80 \\
\hline SNPM-GX-285 & hybrid amorphous monocrystalline & 285.76 & 37.60 & 8.10 & 7.60 \\
\hline NA-V135H1 & hybrid amorphous microcrystalline & 135.36 & 188.00 & 0.87 & 0.72 \\
\hline CHSM5001T-105 & hybrid amorphous microcrystalline & 104.94 & 87.45 & 1.52 & 1.20 \\
\hline
\end{tabular}
photovoltaic modules.

Table 1. Inherent electrical characteristics of photovoltaic modules.

Note: $P_{\max }$ is the maximum output power without shading; $V_{\mathrm{mp}}$ is the output voltage without shading; $I_{\mathrm{SC}}$ is the short-circuit current without shading; and $I_{\mathrm{mp}}$ is the output current without shading.

The temperature is maintained at $25^{\circ} \mathrm{C}$, other factors are kept at standard test conditions and the irradiance is gradually changed from 1000 to $0 \mathrm{~W} / \mathrm{m}^{2}$. The simulation is carried out for the 16 types of photovoltaic modules in Table 1. The relationship between the output power reduction and irradiance under the simulated condition is shown in Figure 2. The curve of each material type in Figure 2 is drawn according to the average value of the power reduction rate of two different models of the photovoltaic module material type. 


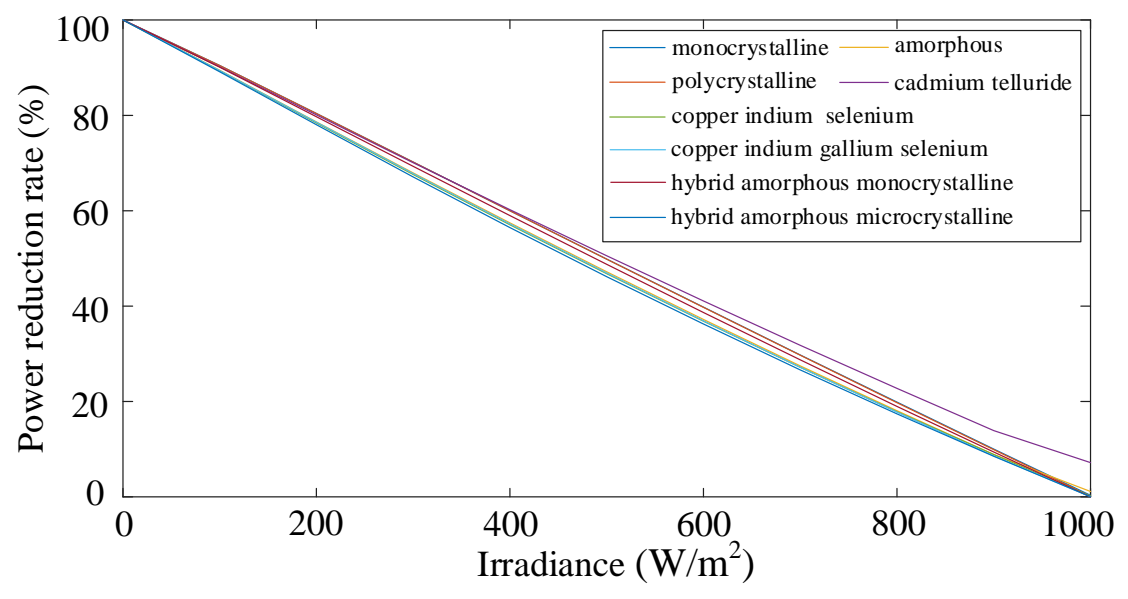

Figure 2. Relationship between the output power reduction rate and irradiance.

Figure 2 shows that the power reduction rate of the photovoltaic module increases with the light irradiance decreases. However, due to the diversity of materials and structures used in different photovoltaic modules, their power reduction rates are different. In order to further explore the relationship between the output power reduction and the light irradiance and provide a theoretical reference for users using photovoltaic power generation systems in partial shading environments, the following research was carried out.

This study simulates shading by changing the light irradiance. Due to the different shading degrees, different parts of the same photovoltaic panel may receive different irradiances. Simulation conditions assume that the irradiance of light on the first solar cell string is $1000 \mathrm{~W} / \mathrm{m}^{2}$, the irradiance of light on the second solar cell string is $300 \mathrm{~W} / \mathrm{m}^{2}$ and the irradiance of light on the third solar cell string is $540 \mathrm{~W} / \mathrm{m}^{2}$ to simulate the light irradiance on the photovoltaic module under actual sun shading. This study was carried out at $25^{\circ} \mathrm{C}$ under standard atmospheric pressure, and other factors affecting the characteristics of the photovoltaic module were kept at STC. No shading means that the irradiance of light on the photovoltaic module is $1000 \mathrm{~W} / \mathrm{m}^{2}$; shading means that the three kinds of light with irradiance of 1000,300 and $540 \mathrm{~W} / \mathrm{m}^{2}$ simultaneously irradiate different parts of the photovoltaic module. These values for light irradiance levels are chosen randomly with reference to the concept that $1000 \mathrm{~W} / \mathrm{m}^{2}$ is the maximum irradiance level for photovoltaic at STC, $540 \mathrm{~W} / \mathrm{m}^{2}$ is the irradiance value around half of the standard irradiance and $300 \mathrm{~W} / \mathrm{m}^{2}$ is the irradiance value which is below half the value of the standard irradiance. These irradiance values were chosen in order to investigate the behavior characteristics of modules receiving different irradiance levels on different parts of their surface area. The findings of this study are very realistic with respect to the simulation conditions and parameters used during the simulation study and it may be possible and allowable for other researchers to carry out similar research work with their own shading irradiance conditions and to draw out their conclusion with respect to their investigation results.

The sum of power transmission factors of the photovoltaic module under shading is

$$
\sum_{j=1}^{g} r=\frac{1000}{1000}+\frac{300}{1000}+\frac{540}{1000}=1.84
$$

Figures 3-10 show the performance parameter change curves of monocrystalline, polycrystalline, amorphous, cadmium telluride, copper indium selenium, copper indium gallium selenium, hybrid amorphous monocrystalline and hybrid amorphous microcrystalline photovoltaic modules, and Table 2 is the summary for the performance parameters of the photovoltaic modules. In the subsequent analysis, the variation rates of power, current and voltage are obtained according to the concept of Equations (9)-(11). 
Table 2. Photovoltaic modules' performance parameters when under shading.

\begin{tabular}{|c|c|c|c|c|c|c|c|}
\hline \multirow[b]{2}{*}{ Types } & \multirow[b]{2}{*}{ Materials } & \multicolumn{6}{|c|}{ Performance Parameters } \\
\hline & & $\begin{array}{l}I_{\mathrm{GMP}} \\
(\mathrm{A})\end{array}$ & $\begin{array}{l}V_{\mathrm{GMP}} \\
\text { (V) }\end{array}$ & $\begin{array}{l}G M P \\
(W)\end{array}$ & $\begin{array}{c}\text { Current } \\
\text { Variation } \\
(\%)\end{array}$ & $\begin{array}{c}\text { Voltage } \\
\text { Variation } \\
(\%)\end{array}$ & $\begin{array}{c}\text { Power } \\
\text { Variation } \\
(\%)\end{array}$ \\
\hline ASEC-245G6S69 & monocrystalline & 3.69 & 89.09 & 328.4 & -58.7 & 8.2 & -27.2 \\
\hline GSM-240 & monocrystalline & 3.26 & 97.05 & 316.2 & -58.4 & 6.0 & -28.1 \\
\hline TSM-240PA05.18 & polycrystalline & 3.27 & 97.43 & 318.6 & -58.2 & 6.8 & -27.8 \\
\hline JKM240P-60B & polycrystalline & 3.31 & 97.46 & 322.2 & -58.4 & 7.5 & -27.1 \\
\hline TWSF-W-aSi-85W-1 & amorphous & 0.38 & 331.30 & 125.6 & -56.4 & 12.6 & -19.9 \\
\hline QS85EGF & amorphous & 0.42 & 287.60 & 120.6 & -57.2 & 9.5 & -23.6 \\
\hline FS-280 & cadmium telluride & 0.47 & 237.00 & 110.5 & -58.3 & 10.9 & -24.7 \\
\hline FS-395 & cadmium telluride & 0.83 & 157.50 & 130.8 & -58.5 & 10.5 & -25.2 \\
\hline SF80-US-P & copper indium selenium & 0.83 & 140.20 & 116.1 & -57.5 & 13.9 & -21.1 \\
\hline SF90-US-B & copper indium selenium & 0.85 & 150.90 & 127.5 & -57.7 & 11.7 & -23.0 \\
\hline STX-130 & copper indium gallium selenium & 0.97 & 193.40 & 187.6 & -57.6 & 13.4 & -21.6 \\
\hline TS-150C1 & copper indium gallium selenium & 1.31 & 160.30 & 209.2 & -58.1 & 11.0 & -24.2 \\
\hline SNPM-GX-220 & $\begin{array}{l}\text { hybrid amorphous } \\
\text { monocrystalline }\end{array}$ & 2.84 & 105.00 & 297.9 & -58.2 & 8.3 & -26.3 \\
\hline SNPM-GX-285 & $\begin{array}{l}\text { hybrid amorphous } \\
\text { monocrystalline }\end{array}$ & 3.16 & 124.20 & 394.4 & -58.4 & 10.1 & -25.0 \\
\hline NA-V135H1 & $\begin{array}{l}\text { hybrid amorphous } \\
\text { microcrystalline }\end{array}$ & 0.31 & 622.00 & 191.9 & -57.2 & 10.3 & -23.0 \\
\hline CHSM5001T-105 & $\begin{array}{l}\text { hybrid amorphous } \\
\text { microcrystalline }\end{array}$ & 0.53 & 303.00 & 160.4 & -55.9 & 15.4 & -16.9 \\
\hline
\end{tabular}

Note: GMP is the global maximum power; $V_{\mathrm{GMP}}$ and $I_{\mathrm{GMP}}$ are the voltage and current at the global maximum power point; - indicates reduction.

Figure 3 shows the simulation results for the monocrystalline module type. Figure 3 a shows that the global maximum power (GMP) of ASEC-245G6S69 is $328.4 \mathrm{~W}$, while the actual maximum output power is $245.04 \mathrm{~W} \cdot 1.84 \approx 450.87 \mathrm{~W}$; its output power decreased by $27.2 \%$, its output current decreased by $58.7 \%$ and its output voltage increased by $8.2 \%$ in the process of changing from no shading to shading. As shown in Figure 3b, for GSM-240, the GMP is $316.2 \mathrm{~W}$, while the actual maximum output power is $239.12 \mathrm{~W} \cdot 1.84 \approx 439.98 \mathrm{~W}$; its output power decreased by $28.1 \%$, its output current decreased by $58.4 \%$ and its output voltage increased by $6.0 \%$ in the process of changing from no shading to shading.
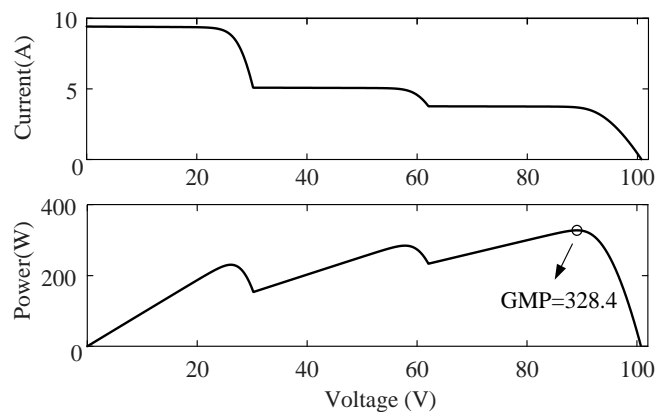

(a) ASEC-245G6S69
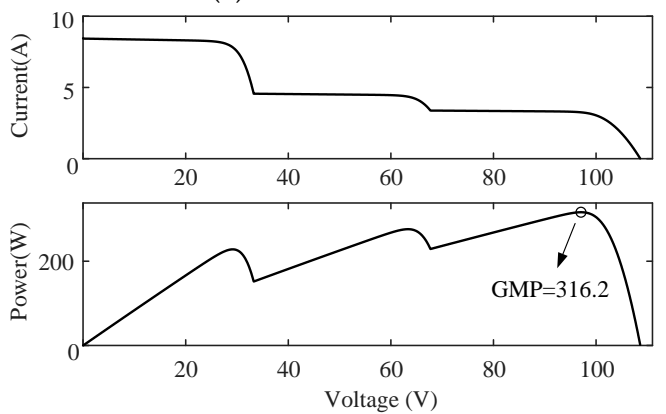

(b) GSM-240

Figure 3. Performance parameter curves of monocrystalline photovoltaic modules. 
Figure 4 shows the simulation results for the polycrystalline PV module type. Figure $4 \mathrm{a}$ shows that the GMP of TSM-240PA05.18 is $318.6 \mathrm{~W}$, while the actual maximum output power is $239.86 \mathrm{~W} \cdot 1.84 \approx 441.34 \mathrm{~W}$; its output power decreased by $27.8 \%$, its output current decreased by $58.2 \%$ and its output voltage increased by $6.8 \%$ in the process of changing from no shading to shading. From Figure $4 \mathrm{~b}$, the GMP of JKM240P-60B is $322.2 \mathrm{~W}$, while the actual maximum output power is $240.09 \mathrm{~W} \cdot 1.84 \approx 441.77 \mathrm{~W}$; its output power decreased by $27.1 \%$, its output current decreased by $58.4 \%$ and its output voltage increased by $7.5 \%$ in the process of changing from no shading to shading.
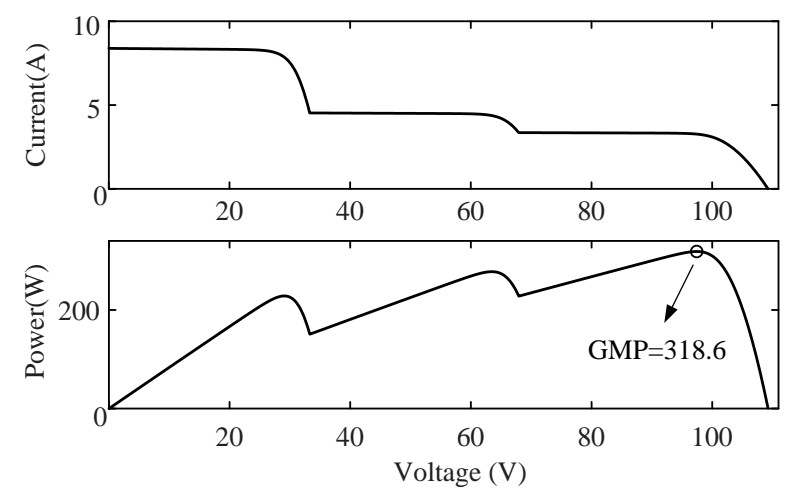

(a) TSM-240PA05.18
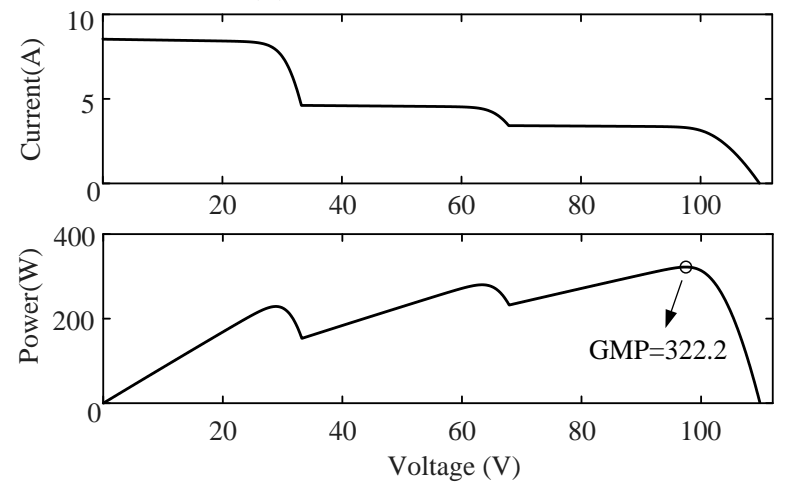

(b) JKM240P-60B

Figure 4. Performance parameter curves of polycrystalline photovoltaic modules.

Figure 5 shows the simulation results for the amorphous photovoltaic module type. Figure $5 \mathrm{a}$ shows that the GMP of TWSF-W-aSi-85W-1 is $125.6 \mathrm{~W}$, while the actual maximum output power is $85.26 \mathrm{~W} \cdot 1.84 \approx 156.88 \mathrm{~W}$; its output power decreased by $19.9 \%$, its output current decreased by $56.4 \%$ and its output voltage increased by $12.6 \%$ in the process of changing from no shading to shading. From Figure $5 \mathrm{~b}$, the GMP of QS85EGF is $120.6 \mathrm{~W}$, while the actual maximum output power is $85.75 \mathrm{~W} \cdot 1.84 \approx 157.78 \mathrm{~W}$; its output power decreased by $23.6 \%$, its output current decreased by $7.2 \%$ and its output voltage increased by $9.5 \%$ in the process of changing from no shading to shading.

Figure 6 shows the simulation results for the cadmium telluride photovoltaic module type. Figure 6a shows that the GMP of FS-280 is $110.5 \mathrm{~W}$, while the actual maximum output power is $79.74 \mathrm{~W} \cdot 1.84 \approx 146.72 \mathrm{~W}$; its output power decreased by $24.7 \%$, its output current decreased by $58.3 \%$ and its output voltage increased by $10.9 \%$ in the process of changing from no shading to shading. Figure $6 \mathrm{~b}$ shows that the GMP of FS-395 is $130.8 \mathrm{~W}$, while the actual maximum output power is $95.00 \mathrm{~W} \cdot 1.84 \approx 174.80 \mathrm{~W}$; its output power decreased by $25.2 \%$, its output current decreased by $58.5 \%$ and its output voltage increased by $10.5 \%$ in the process of changing from no shading to shading. 


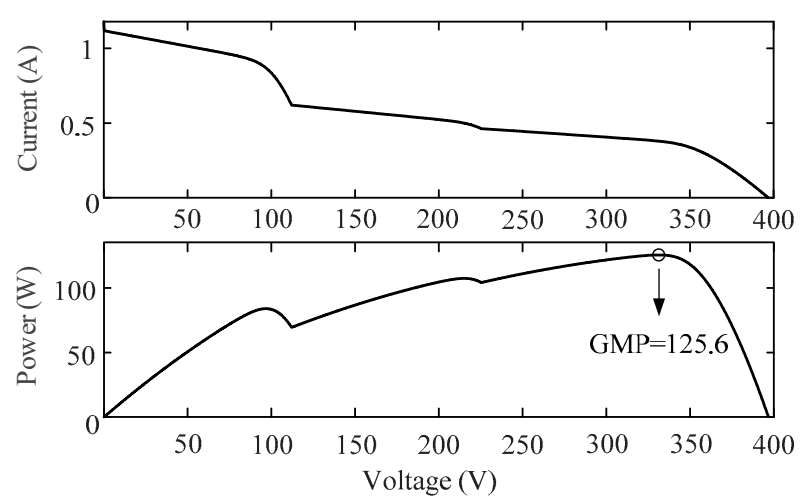

(a) TWSF-W-aSi-85W-1
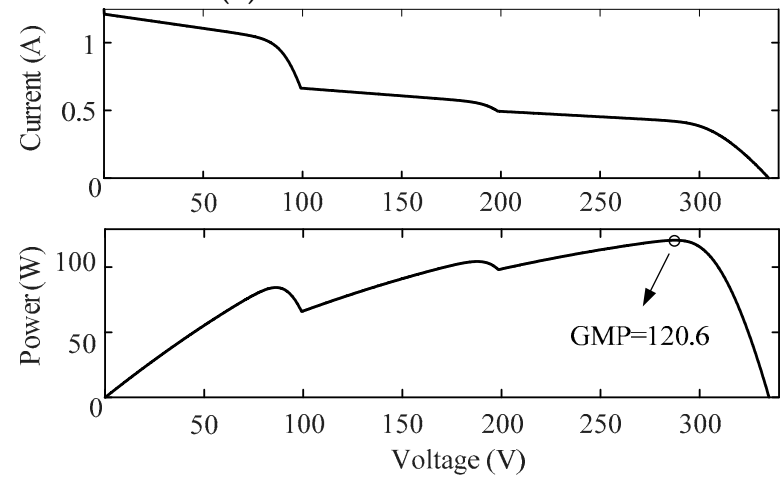

(b) QS85EGF

Figure 5. Performance parameter curves of amorphous photovoltaic modules.
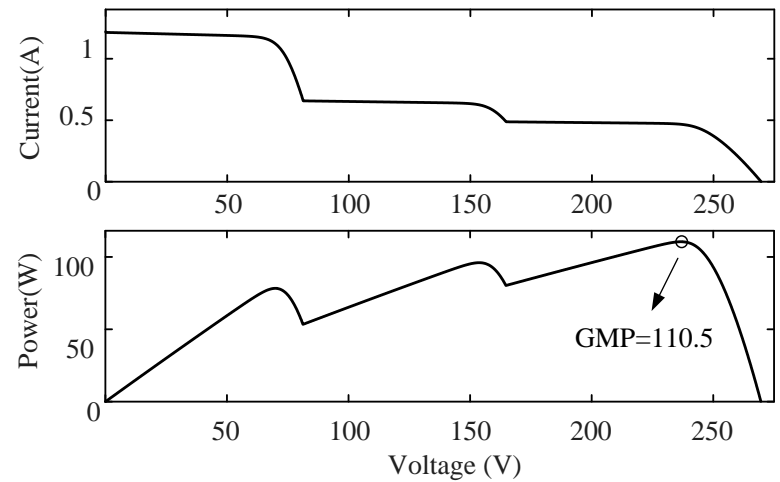

(a) FS-280
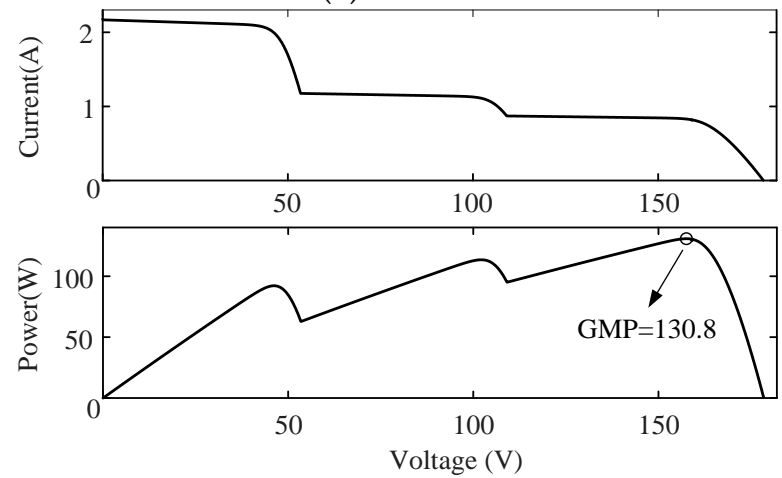

(b) FS-395

Figure 6. Performance parameter curves of cadmium telluride photovoltaic modules. 
Figure 7 shows the simulation results for the copper indium selenium photovoltaic module type. Figure 7a shows that the GMP of SF80-US-P is $116.1 \mathrm{~W}$, while the actual maximum output power is $79.95 \mathrm{~W} \cdot 1.84 \approx 147.11 \mathrm{~W}$; its output power decreased by $21.1 \%$, its output current decreased by $57.5 \%$ and its output voltage increased by $13.9 \%$ in the process of changing from no shading to shading. Figure $7 \mathrm{~b}$ shows that the GMP of SF90-US-B is $127.5 \mathrm{~W}$, while the actual maximum output power is $90.00 \mathrm{~W} \cdot 1.84 \approx 165.60 \mathrm{~W}$; its output power decreased by $23.0 \%$, its output current decreased by $57.7 \%$ and its output voltage increased by $11.7 \%$ in the process of changing from no shading to shading.

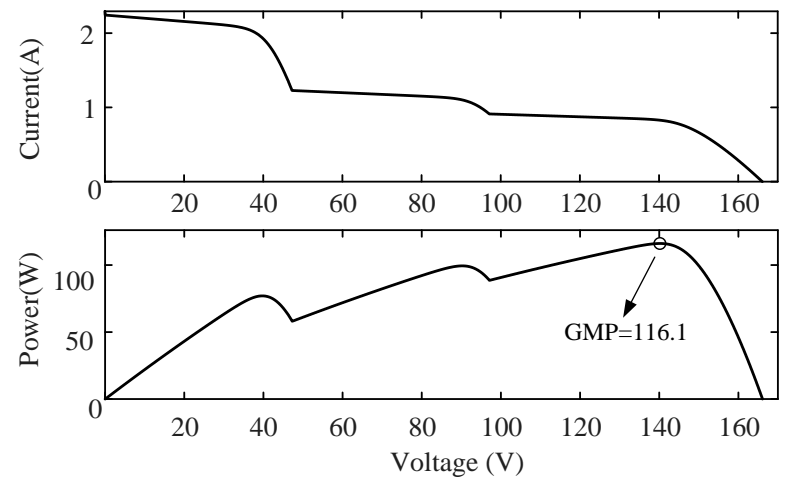

(a) SF80-US-P
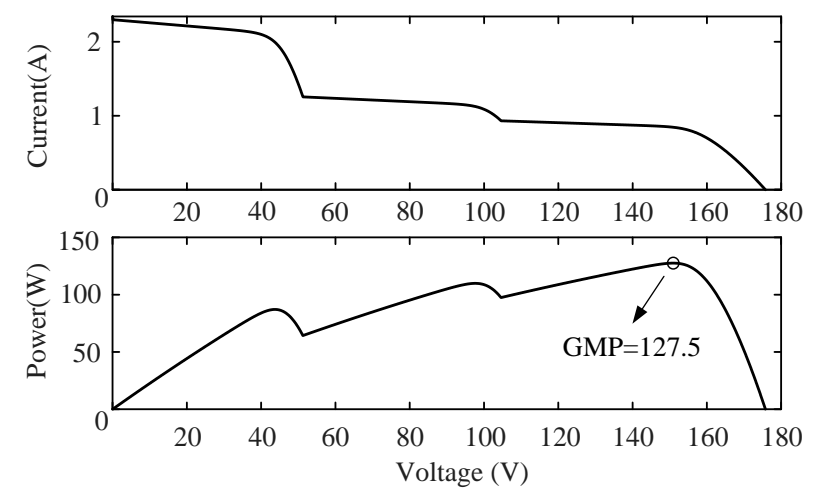

(b) SF90-US-B

Figure 7. Performance parameter curves of copper indium selenium photovoltaic modules.

Figure 8 shows the simulation results for the copper indium gallium selenium photovoltaic module type. Figure $8 \mathrm{a}$ indicates that the GMP of STX-130 is $187.6 \mathrm{~W}$, while the actual maximum output power is $130.00 \mathrm{~W} \cdot 1.84 \approx 239.20 \mathrm{~W}$; its output power decreased by $21.6 \%$, its output current decreased by $57.6 \%$ and its output voltage increased by $13.4 \%$ in the process of changing from no shading to shading. From Figure 8 b, the GMP of TS-150C1 is $209.2 \mathrm{~W}$, while the actual maximum output power is $150.07 \mathrm{~W} \cdot 1.84 \approx 276.13 \mathrm{~W}$; its output power decreased by $24.2 \%$, its output current decreased by $58.1 \%$ and its output voltage increased by $11.0 \%$ in the process of changing from no shading to shading.

Figure 9 shows the simulation results for the hybrid amorphous monocrystalline photovoltaic module type. Figure 9a shows that the GMP of SNPM-GX-220 is $297.9 \mathrm{~W}$, while the actual maximum output power is $219.64 \mathrm{~W} \cdot 1.84 \approx 404.14 \mathrm{~W}$; its output power decreased by $26.3 \%$, its output current decreased by $58.2 \%$ and its output voltage increased by $8.3 \%$ in the process of changing from no shading to shading. From Figure 9b, the GMP of SNPM-GX-285 is $394.4 \mathrm{~W}$, while the actual maximum output power is $285.76 \mathrm{~W} \cdot 1.84 \approx 525.80 \mathrm{~W}$; its output power decreased by $25.0 \%$, its output current decreased by $58.4 \%$ and its output voltage increased by $10.1 \%$ in the process of changing from no shading to shading. 

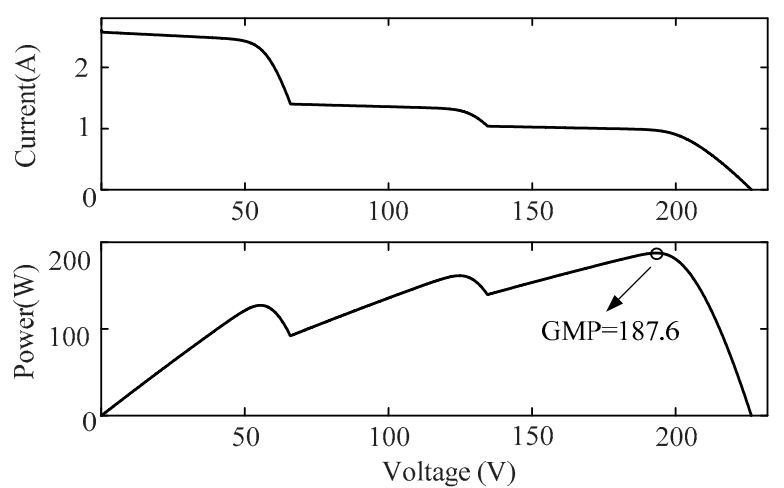

(a) STX-130
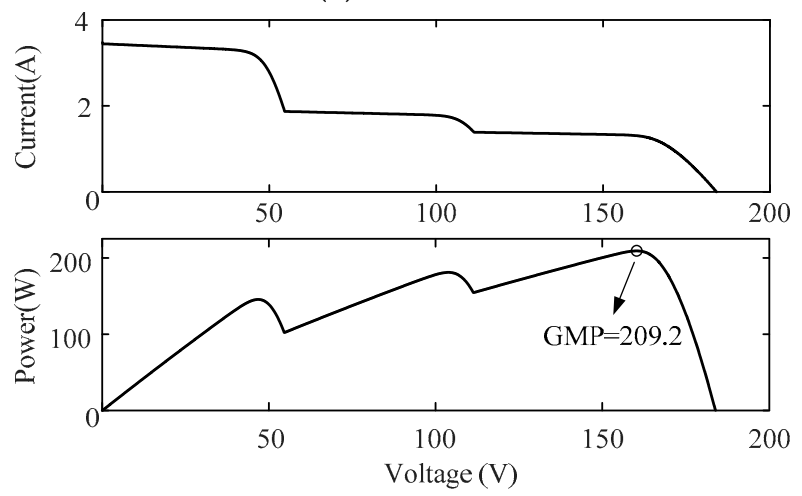

(b) TS-150C1

Figure 8. Performance parameter curves of copper indium gallium selenium photovoltaic modules.
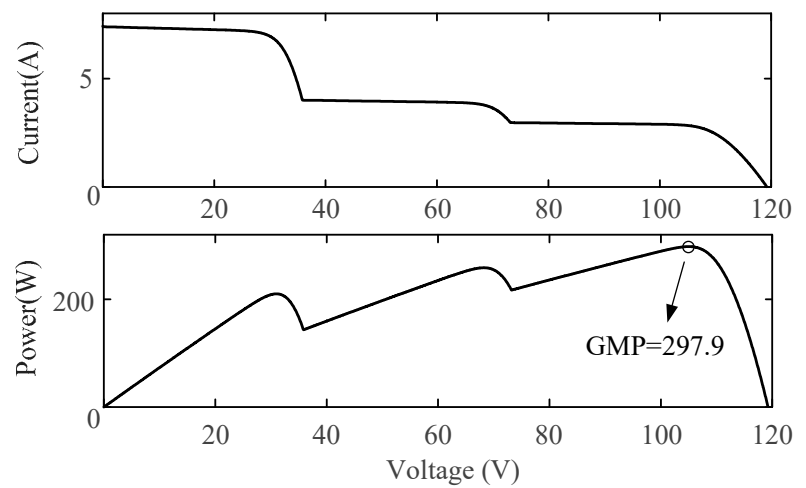

(a) SNPM-GX-220
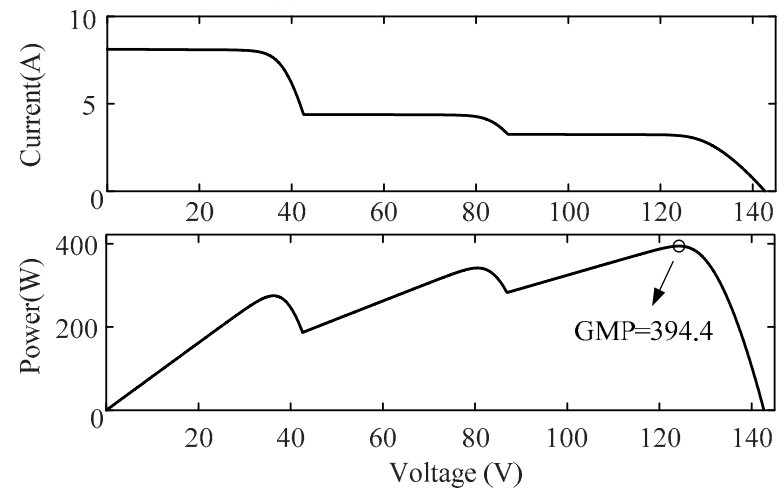

(b) SNPM-GX-285

Figure 9. Performance parameter curves of hybrid amorphous monocrystalline photovoltaic modules. 
Figure 10 shows the simulation results for the hybrid amorphous microcrystalline photovoltaic module type. Figure 10a shows that the GMP of NA-V135H1 is $191.9 \mathrm{~W}$, while the actual maximum output power is $135.36 \mathrm{~W} \cdot 1.84 \approx 249.06 \mathrm{~W}$; its output power decreased by $23.0 \%$, its output current decreased by $57.2 \%$ and its output voltage increased by $10.3 \%$ in the process of changing from no shading to shading. From Figure 10b, the GMP of CHSM5001T-105 is $160.4 \mathrm{~W}$, while the actual maximum output power is $104.94 \mathrm{~W} \cdot 1.84 \approx 193.09 \mathrm{~W}$; its output power decreased by $16.9 \%$, its output current decreased by $55.9 \%$ and its output voltage increased by $15.4 \%$ in the process of changing from no shading to shading.
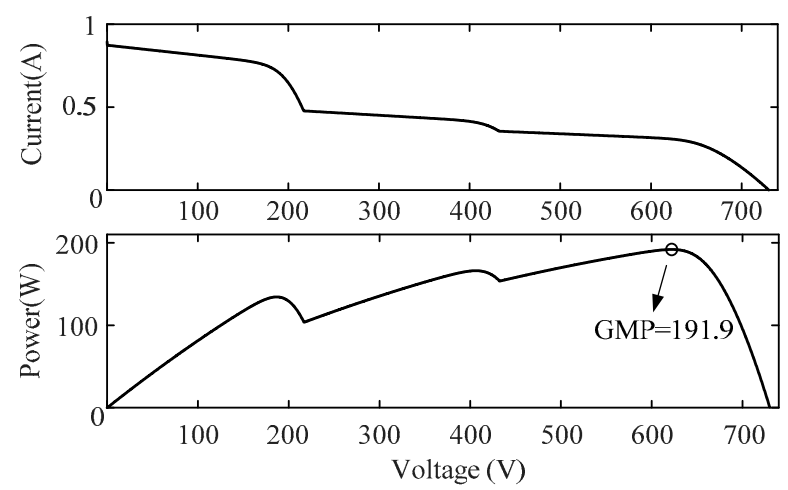

(a) NA-V135H1
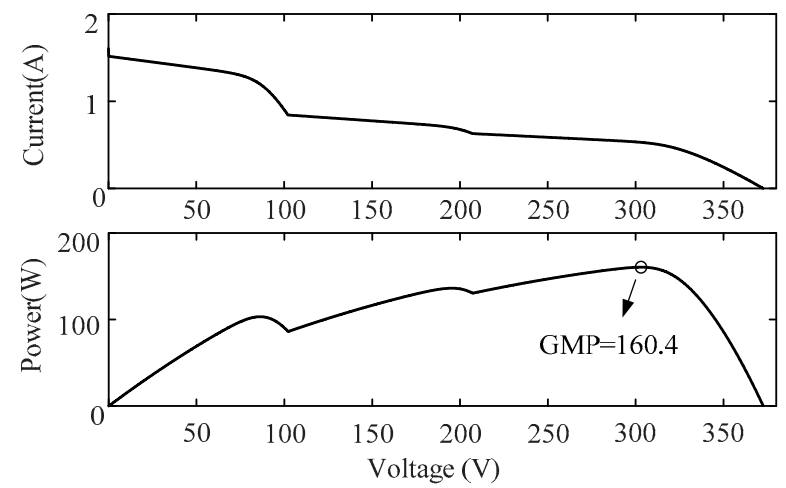

(b) CHSM5001T-105

Figure 10. Performance parameter curves of hybrid amorphous microcrystalline photovoltaic modules.

Table 2 shows that the voltage and current of photovoltaic modules change from no shading to shading. Specifically, when shaded, the voltage of photovoltaic modules increases, while the current is greatly reduced; this is expressed through the relationship between power, voltage and current $(\mathrm{P}=\mathrm{UI})$, and the slight rise in the voltage and the sharp drop in the current eventually lead to the reduction in the photovoltaic modules' output power.

As can be seen from the column of "types" in Table 2, two photovoltaic models were simulated and analyzed for each photovoltaic material in order to make the research more universal and realistic; similarly, the column of "power variation (\%)" represents power reduction percentages and they appear in two percentage values because two photovoltaic modules were selected for each material in the study (two percent in power reduction percentage values can be interpreted scientifically as a power variation range for one typical photovoltaic material). The power variation percentages, as shown in Table 2, are calculated with reference to the output power of the photovoltaic module once it is considered to be receiving STC irradiance $\left(1000 \mathrm{~W} / \mathrm{m}^{2}\right)$ and with reference to the logical concept of Equation (9). When under shading, the output power of monocrystalline photovoltaic modules is reduced within the range of $27.2 \%$ to $28.1 \%$; the output power of polycrystalline photovoltaic modules is reduced within the range of $27.1 \%$ to $27.8 \%$; the output power of amorphous photovoltaic modules is reduced within the range of $19.9 \%$ to $23.6 \%$; the output power of cadmium telluride photovoltaic modules is 
reduced within the range of $24.7 \%$ to $25.2 \%$; the output power of copper indium selenium photovoltaic modules is reduced within the range of $21.1 \%$ to $23.0 \%$; the output power of copper indium gallium selenium photovoltaic modules is reduced within the range of $21.6 \%$ to $24.2 \%$; the output power of hybrid amorphous monocrystalline photovoltaic modules is reduced within the range of $25.0 \%$ to $26.3 \%$; and the output power of hybrid amorphous microcrystalline photovoltaic modules is reduced within the range of $16.9 \%$ to $23.0 \%$.

Since monocrystalline photovoltaic modules and polycrystalline photovoltaic modules belong to crystalline photovoltaic modules, and amorphous photovoltaic modules, cadmium telluride photovoltaic modules, copper indium selenium photovoltaic modules, copper indium gallium selenium photovoltaic modules, hybrid amorphous monocrystalline photovoltaic modules and hybrid amorphous microcrystalline photovoltaic modules belong to thin film photovoltaic modules, the power of crystalline photovoltaic modules is reduced more than that of thin film photovoltaic modules when under shading, that is, thin film photovoltaic modules have better adaptability to shading than crystalline photovoltaic modules.

\section{Concluding Remarks}

The aggravation of the energy crisis promotes the rapid development of renewable energy such as wind energy and solar energy. The investment cost is among parameters when there is consideration of renewable energy exploitation. For example, once the photovoltaic panels are blocked by clouds and leaves during the development of solar energy, it becomes hard for the photovoltaic panels' output power to meet the established load requirement, which leads the increase in installed capacity in order to meet the load demand. A simulation model of photovoltaic modules is established with the symmetry concept, and this study is meaningful as it focuses on shading effects of photovoltaic modules made of various materials and structures (two types of crystalline photovoltaic modules and six types of thin film photovoltaic modules). The conclusions are summarized as follows.

- The output power of the photovoltaic module is directly proportional to the irradiance of the applied light level.

- The output voltage of the photovoltaic module slightly increases and the output current greatly decreases from no shading (the irradiance of light shining on the photovoltaic panel is $1000 \mathrm{~W} / \mathrm{m}^{2}$ ) to shading (light with irradiance of 1000,300 and $540 \mathrm{~W} / \mathrm{m}^{2}$ shines on different parts of the photovoltaic panel at the same time).

- The output power reduction rate of different photovoltaic modules is different when the irradiance changes. Specifically, from no shading to shading, the output power of monocrystalline photovoltaic modules and polycrystalline photovoltaic modules, which belong to crystalline photovoltaic modules, reduced within the ranges of $27.2-28.1 \%$ and $27.1-27.8 \%$, respectively. The output power of amorphous photovoltaic modules, cadmium telluride photovoltaic modules, copper indium selenium photovoltaic modules, copper indium gallium selenium photovoltaic modules, hybrid amorphous monocrystalline photovoltaic modules and hybrid amorphous microcrystalline photovoltaic modules, which belong to thin film photovoltaic modules, reduced within the ranges of $19.9-23.6 \%, 24.7-25.2 \%, 21.1-23.0 \%, 21.6-24.2 \%, 25.0-26.3 \%$ and $16.9-23.0 \%$, respectively.

- The power reduction rate of thin film photovoltaic modules is lower than that of crystalline photovoltaic modules when they are shaded; therefore, it is confirmed to use thin film photovoltaic modules in photovoltaic power generation environments where shading cannot be avoided. The findings in this study are helpful to improve the power production efficiency, reduce the investment cost of renewable energy generation systems and promote the development and utilization of renewable energy. 
Further works are recommended to analyze and compare shade impact and effects on PV characteristics considering other types of PV module types which are not covered by this paper such as photovoltaic modules composed of organic cells, biological hybrid photovoltaic cells, concentrated photovoltaic cells, non-concentrated heterogeneous photovoltaic cells, solid-state photovoltaic cells and nano-photovoltaic cells, in order to provide a more comprehensive selection basis for photovoltaic users. This study used Matlab Simulink, and further investigations are recommended to be conducted using SimScape in order to explore more detailed concluding results and other aspects, such as how partial shading affects the local temperature distribution in a photovoltaic module.

Author Contributions: Formal analysis, G.L.; Funding acquisition, L.L.; Methodology, Y.L.; Software, C.-H.W.; Visualization, M.-L.T.; Writing-original draft, S.B.; Writing-review \& editing, M.-L.T. All authors have read and agreed to the published version of the manuscript.

Funding: This research was funded by the key project of Tianjin Natural Science Foundation [Project No. 19JCZDJC32100], the Natural Science Foundation of Hebei Province of China [Project No. E2018202282] and MOST 109-2918-I-468-001-, Taiwan.

Conflicts of Interest: The authors declare no conflict of interest.

\section{References}

1. Taylor, T.G.; Tainter, J.A. The nexus of population, energy, innovation, and complexity. Am. J. Econ. Sociol. 2016, 75, 1005-1043. [CrossRef]

2. Papadopoulou, S.D.; Kalaitzoglou, N.; Psarra, M.; Lefkeli, S. Addressing energy poverty through transitioning to a carbon-free environment. Sustainability 2019, 11, 2634. [CrossRef]

3. Li, L.L.; Liu, Y.W.; Tseng, M.L. Reducing environmental pollution and fuel consumption using optimization algorithm to develop combined cooling heating and power system operation strategies. J. Clean. Prod. 2019, 247, 119082. [CrossRef]

4. Gielen, D.; Boshell, F.; Saygin, D. The role of renewable energy in the global energy transformation. Energy Strategy Rev. 2019, 24, 38-50. [CrossRef]

5. Liu, Z.F.; Li, L.L.; Tseng, M.L.; Lim, M.K. Prediction short-term photovoltaic power using improved chicken swarm optimizer-Extreme learning machine model. J. Clean. Prod. 2020, 248, 119272. [CrossRef]

6. Wang, J.D. A Short-Term Photovoltaic Power prediction model based on the gradient boost decision tree. Appl. Sci. 2018, 8, 689. [CrossRef]

7. Wang, Z.; Zhang, Z.M.; Quan, X. A perfect absorber design using a natural hyperbolic material for harvesting solar energy. Sol. Energy 2018, 159, 329-336. [CrossRef]

8. Abedinia, O.; Amjady, N.; Ghadimi, N. Solar energy forecasting based on hybrid neural network and improved metaheuristic algorithm. Comput. Intell. 2018, 34, 241-260. [CrossRef]

9. Li, L.L.; Wen, S.Y.; Tseng, M.L.; Chiu, A.S.F. Photovoltaic array prediction on short-term output power method in centralized power generation system. Ann. Oper. Res. 2020, 290, 243-263. [CrossRef]

10. Li, L.L.; Li, H.Y.; Tseng, M.L.; Feng, H.; Chiu, A.S.F. Renewable energy system on frequency stability control strategy using virtual synchronous generator. Symmetry 2020, 12, 1697. [CrossRef]

11. Yuan, F.; Li, M.J.; Qiu, Y. Specific heat capacity improvement of molten salt for solar energy applications using charged single-walled carbon nanotubes. Appl. Energy 2019, 250, 1481-1490. [CrossRef]

12. Pannebakker, B.B.; De Waal, A.C. Photovoltaics in the shade: One bypass diode per solar cell revisited. Prog. Photovolt. Res. Appl. 2017, 25, 836-849. [CrossRef]

13. Bi, Z.; Ma, J.; Pan, X.; Wang, J.; Chi, Y. ANFIS-Based modeling for photovoltaic characteristics estimation. Symmetry 2016, 8, 96. [CrossRef]

14. Yang, W.S.; Noh, J.H.; Jeon, N.J. High-performance photovoltaic perovskite layers fabricated through intramolecular exchange. Science 2015, 348, 1234-1237. [CrossRef] [PubMed]

15. Ye, Q.; Xu, Y.; Chen, W. Enhanced photovoltaic performance of Sb_2S_3-sensitized solar cells through surface treatments. Appl. Surf. Sci. 2018, 440, 294-299. [CrossRef] 
16. Alfadhili, F.K.; Phillips, A.B.; Liyanage, G.K.; Gibbs, J.M.; Jamarkattel, M.K.; Heben, M.J. Controlling band alignment at the back interface of cadmium telluride solar cells using ZnTe and Te buffer layers. MRS Adv. 2019, 4, 1-7. [CrossRef]

17. Doroody, C.; Rahman, K.S.; Rosly, H.N. Impact of high resistivity transparent (HRT) layer in cadmium telluride solar cells from numerical simulation. J. Renew. Sustain. Energy 2020, 12, 23702. [CrossRef]

18. Montoya, O.D.; Grisales-Noreña, L.F.; Gil-González, W.; Alcalá, G.; Hernandez-Escobedo, G. Optimal location and sizing of PV sources in DC networks for minimizing greenhouse emissions in diesel generators. Symmetry 2020, 12, 322. [CrossRef]

19. Saini, R.P. Feasibility and sensitivity analysis of an off-grid micro hydro-photovoltaic-biomass and biogas-diesel-battery hybrid energy system for a remote area in Uttarakhand state, India. Renew. Sustain. Energy Rev. 2016, 61, 53-69.

20. Aramesh, M.; Kasaeian, A.; Pourfayaz, F. A detailed investigation of the walls shading effect on the performance of solar ponds. Environ. Prog. Sustain. Energy 2018, 38, e13014. [CrossRef]

21. Teo, J.; Tan, R.; Mok, V.; Ramachandaramurthy, V.K.; Tan, C. Impact of partial shading on the PV characteristics and the maximum power of a photovoltaic string. Energies 2018, 11, 1860. [CrossRef]

22. Green, M.A. Crystalline and thin-film silicon solar cells: State of the art and future potential. Sol. Energy 2003, 74, 181-192. [CrossRef]

23. Niazi, K.A.; Yang, Y.; Nasir, M.; Sera, D. Evaluation of interconnection configuration schemes for PV modules with switched-inductor converters under partial shading conditions. Energies 2019, 12, 2802. [CrossRef]

24. Cai, L.; Dai, N.; Tan, Z. Research on mathematical model and calculation simulation of wireless sensor solar cells in internet of things. EURASIP J. Wirel. Commun. Netw. 2018, 116. [CrossRef]

25. Kreft, W.; Filipowicz, M.; Odek, M. Reduction of electrical power loss in a photovoltaic chain in conditions of partial shading. Opt. Int. J. Light Electron. Opt. 2019, 202, 163559. [CrossRef]

26. Polman, A.; Knight, M.; Garnett, E.C. Photovoltaic materials: Present efficiencies and future challenges. Science 2016, 352, aad4424. [CrossRef]

27. Vulkan, A.; Kloog, I.; Dorman, M. Modeling the potential for PV installation in residential buildings in dense urban area. Energy Build. 2018, 169, 97-109. [CrossRef]

28. Hamakawa, Y. Thin-film solar cells: Next generation photovoltaics and its applications. Springer 2004, $26,894-897$.

29. Chu, T.L.; Chu, S.S. Recent progress in thin-film cadmium telluride solar cells. Prostate 2010, 1, 31-42. [CrossRef]

30. Luceño-Sánchez, J.A.; Díez-Pascual, A.M.; Peña, C.R. Materials for photovoltaics: State of art and recent developments. Int. J. Mol. Sci. 2019, 20, 976. [CrossRef]

31. Hegedus, S. Thin film solar modules: The low cost, high throughput and versatile alternative to Si wafers. Prog. Photovolt. Res. Appl. 2006, 14, 393-411. [CrossRef]

32. Wu, W.W.; Lee, Y.T.; Tseng, M.L.; Chiang, Y.H. Data mining for exploring hidden patterns between KM and its performance. Knowl. Based Syst. 2010, 23, 397-401. [CrossRef]

33. Zhou, D.L.; Gan, Z.K.; Liao, D. Research Progress of a-Si: H Thin Film Solar Cells. Chin. J. Power Sources 2018, 744-746. Available online: http://en.cnki.com.cn/Article_en/CJFDTotal-DYJS201805046.htm (accessed on 15 December 2020).

34. Sharma, S.; Jain, K.K.; Sharma, A. Solar cells: In research and applications-A review. Mater. Sci. Appl. 2015, 6, 1145-1155. [CrossRef]

35. Sarti, D.; Einhaus, R. Silicon feedstock for the multi-crystalline photovoltaic industry. Sol. Energy Mater. Sol. Cells 2002, 72, 27-40. [CrossRef]

36. Chrzan, D.C. MATERIALS SCIENCE: Metallurgy in the age of silicon. Science 2005, 310, 1623-1624. [CrossRef]

37. Magdi, S.; El, R.J.; Swillam, M. Litho-free fabrication of crystalline silicon nanowires using amorphous silicon substrate for wide-angle energy absorption applications. ACS Appl. Nano Mater. 2018, 1, 2990-2996. [CrossRef]

38. Choi, S.; Ishii, T.; Sato, R. Performance degradation due to outdoor exposure and seasonal variation in amorphous silicon photovoltaic modules. Thin Solid Films 2018, 661, 116-121. [CrossRef]

39. Patel, H.; Agarwal, V. Matlab-based modeling to study the effects of partial shading on PV array characteristics. IEEE Trans. Energy Convers. 2008, 23, 302-310. [CrossRef] 
40. Liu, X.; Qi, X.; Zheng, S. Model and analysis of photovoltaic array under partial shading. Power Syst. Technol. 2010, 324, 192-197.

41. Zhao, H.; Li, H.P.; Wang, H.J. Model and analytical investigation of PV module under partial shading. Chin. J. Power Source 2015, 71-74. Available online: http://en.cnki.com.cn/Article_en/CJFDTotal-DYJS201501030.htm (accessed on 15 December 2020).

Publisher's Note: MDPI stays neutral with regard to jurisdictional claims in published maps and institutional affiliations.

(C) 2020 by the authors. Licensee MDPI, Basel, Switzerland. This article is an open access article distributed under the terms and conditions of the Creative Commons Attribution (CC BY) license (http://creativecommons.org/licenses/by/4.0/). 